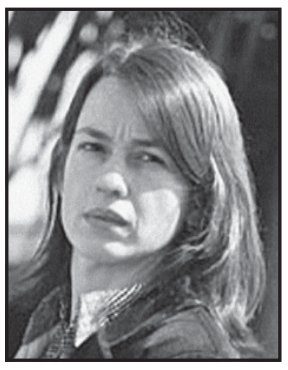

LAURA C. PAUTASSI

Lawyer, major in Social Policy Planning and M anagement from the University of Buenos Aires, with a P hD in Law and Social Sciences. Researcher for the Consejo de Investigaciones Científicas y Tecnológicas (CONICET), Instituto de Investigaciones J urídicas y Sociales "A mbrosio Gioja", Law Faculty, U niversity of Buenos Aires, Argentina. Postgraduate P rofessor.

Address: I nstituto de Investigaciones J urídicas y Sociales A. Gioja

Facultad de Derecho, U niversidad de Buenos Aires

Av. Figueroa Alcorta 2263, 1 piso - C1425CKB-Buenos Aires, Argentina

E mail: Ipautassi@arnet.com.ar

\title{
ABST RACT
}

This paper reflects on the various steps that have been taken in Latin America towards assuring equality between men and women, through the different strategies and affirmative actions that have been applied in various fields (labor relations, family-work reconciliation, social security). The analysis concentrates on the responsibility of the State when it comes to labor regulations, primarily the legal principle of equal treatment and the right to social security. The paper distinguishes between the concepts of discrimination and inequality, and analyzes the principles of gender equality and differences that can be found in labor and social security laws. From there, some public policy proposals shall be presented that promote new institutional frameworks, in particular for the pension system, but also for conciliatory policies and employment in general.

O riginal in Spanish. Translated by Barney W hiteoak.

\section{KEYWORDS}

Equality - D iscrimination - Social rights - Focus of rights - G ender policies -Affirmative action - Labor market - Social security

(c) This paper is published under the creative commons license.

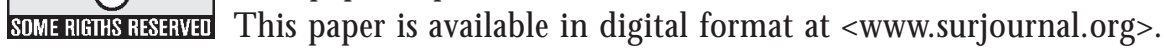




\section{IS THERE EQUALITY IN INEQUALITY? SCOPE AND LIMITS OF AFFIRMATIVE ACTIONS}

Laura C. Pautassi

\section{Introduction}

0 ver the past two decades, the principles of political, economic and social organization in Latin America have undergone a process of transformation. First, through the sustained implementation of structural and State reform policies in the region that, while taking on different characteristics in each country, gave rise to a series of policies and measures with a clear objective. The goal was to restructure the State by changing the ways it traditionally used to function, through a growing subrogation of its functions accompanied by in-depth internal economic transformations, with new social and economic agents, and with the implementation of new forms of protection and social security.

O ne phenomenon that has altered the profile of the region's social agenda was the entrance of women into public life, both through their incorporation into the labor market, through the visible advances in education and through an incipient - yet still insufficient - engagement in terms of political participation. $\mathrm{N}$ evertheless, this has not produced in men the same acceptance of responsibility for reproductive tasks, that have been historically female.

As such, men and women have been affected by the application of reform policies in numerous ways, primarily concerning their status in the labor market, particularly given the changes in hiring methods, with part-time contracts, labor mobility and outsourcing, the loss of social benefits that were previously standard in stable employment, severe restrictions in the system 
of social policies, rising unemployment and underemployment, not to mention lower salaries, if they even exist.

Running in parallel to these situations of vulnerability, and paradoxically during the reform processes in the region, women have managed to secure legal recognition and formal equality in all countries across the region. The majority of the States have ratified key human rights treaties and in due course they adapted their national legal frameworks to accommodate these international instruments. They also introduced affirmative action measures, recognized reproductive rights and indeed all countries created jurisdictional mechanisms to further equality policies. Women's organizations, with their age-old struggles, also pressured their governments for a gender agenda, seeking to consolidate strategies and key policies to promote equality and introduce a debate on citizenship for men and women.

$\mathrm{O} n$ the other hand, as Castel points out, the discourse on the incorporation of women into the labor market occurs precisely at the time when work, as a privileged element in the social relation, is devalued, while the market is affected by the ever more notable and demanding presence of women who exert pressure on it and demand efficiency and results from politicians. ${ }^{1}$

This is the context in which the asymmetries of Latin American institutional development become explicit. First, the sum of the actions taken by different social and political agents has produced a framework of rights and consensuses to promote gender equality. $N$ evertheless, the results are far from satisfactory: poverty, discrimination and inequality persist and embody in social exclusion the great "phenomenon" of countries in the region. This means that there has been an increase in the asymmetry when it comes to human rights, considering that the current stage of development and inclusion in productive work has generated an unparalleled contrast between a greater realization of civil and political rights and a dramatic setback in the realization of social and economic rights. M eanwhile, socio-economic insecurity and social vulnerability have deteriorated, with an impact on gender.

This situation reflects a weak - but no less important - link between the spheres of citizenship and the true scope of the principle of equal opportunities and treatment. It is necessary here to make a clarification: the law in general - and labor law in particular - reveals the ongoing tension between the regulation of the public sphere and the liberal view of a State that does not meddle in private affairs, which should be free from State intervention. ${ }^{2}$

In fact, and as I shall argue throughout this article, labor laws have transposed the traditional boundary between public and private, ${ }^{3}$ standing between the two and upsetting the equality between the contractual parties. They establish that, given the relationship of subordination characterizing 
the employment contract, the working party requires special attention. In addition, this branch of law presents a dichotomy in which two distinct values compete: on the one hand we accept the validity of the principle of equality among workers; on the other, we complain about the different rules for certain principles. This dichotomy, which may also be considered a tension, is particularly important when it comes to female work, which involves reproductive cycles and the subsequent social relations that imply the need to assume both family as well as productive working responsibilities. This relationship becomes so complicated that difference is used to claim equality.

H owever, this legal recognition of difference to assure rights to provide effective equal opportunities for women does not take into account the gender division of work in the home, where the male worker rarely assumes any active co-responsibility for reproductive tasks. This deepens the divide between the public and the private, without enough consideration for the existing conflicts in these two spheres and relegating to the private sphere the particularities and differences of gender. In other words, what is protected and regulated for women is related to their responsibility in the private world, and not the productive-reproductive continuum as a point of analysis of relationships involving men and women, or the elimination of discrimination in the public world. ${ }^{5}$

In my argument, I emphasize that this recognition of rights in the field of labor and social security law does not al ways represent a recognition of the rights of women. This means that although rules and principles have been incorporated that recognize equality in the workplace, the legal substratum does not consider women as individuals with inherent rights of their own, but instead that their rights derive from their inclusion in the formal labor market or from their bond to another rights holder (her husband or father), who are also not considered as such: their rights derive from their status as a paid worker.

This treatment of women in the social security system as holders of rights that are derived, i.e. not their own, characterizes the organization and development of social policy systems in Latin America. Concerning their inclusion in the labor market, the idea of a "derived" rights holder influences the majority of labor regulations and has, doubtless, become embedded in the workings of the labor market, among other reasons because the inclusion of women in this market was never even contemplated.

H owever, this organizational form of the system can be remedied with a series of interventions such as the ones I shall propose later in this paper, which will contribute to creating fairer systems, to which access will be based not on rights derived from employment or from a legal bond with a worker, but in virtue of one's status as a citizen, male and female alike. ${ }^{6}$ 
Given this situation, I intend in this article to analyze the scope of the treatment of women as individuals with derived rights in the sphere of social security, and the role of the reforms in the consolidation of this category. As a result, I shall pay special attention to the pension reforms and their effects on men and women.

To put the debate into context, I shall first examine the responsibility of the State concerning labor regulations, drawing heavily on the legal principle of equal treatment, the right to social security, distinguishing between the concepts of discrimination and inequality, and analyzing the principles of gender equality and differences found in labor and social security regulations. From there, I shall present some public policy proposals that, while not intended to be definitive, aim to explore new areas and approaches for incorporating into the political arena, and also into the State agenda, the needs for new institutional frameworks to remedy the inequalities that currently prevail.

\section{Labor law: the first affirmative action?}

Labor law is a branch of autonomous law that warrants State intervention in legal relationships between independent parties. This intervention is justified on the grounds that there is a pre-existing inequality between the two parties in the relationship, based on their different economic status and hierarchical position: one of the parties, the employer, holds sway over the other party, the employee, who obeys him and performs the agreed upon services in exchange for a salary. This has given rise to a distinctive legal structure, one that serves the industrial capitalist system that regulates both individual relations between employer and employee, and collective relations between bosses and unions. This incorporation of collective subjects that are authorized to act is unprecedented and empowers group subjects to set hiring rules for certain spheres of productive activity.

Unlike other branches of the law, such as civil law or commercial law, which protect the parties' autonomous will and endorses the freedom of contract, labor law acknowledges the need to lend social protection to those in a subordinate employment relationship or whose economic or legal situation is recognizably disadvantageous compared to the other party. In this context, labor law is not based on the premise of equality between the contracting parties. In contrast, its goal or aspiration is substantive equality and, to achieve this, it lends special protection to the weaker party in labor relationships. ${ }^{7}$

Concerning the specific regulation for women workers, it is worth noting that the first labor rules emerged specifically to protect women and children 
who were exploited during the industrial revolution. For this reason, the rules originated from the intention to protect women from the demanding labor conditions that existed at the time, either from working the night shift or in unsanitary or hazardous environments, while considering women only in their role as mothers - provisions that were introduced principally by ILO protection conventions. ${ }^{8}$

In the mid 1940s, when Latin American countries were building the foundations of the Welfare State, women continued to be treated as mothers, a situation that is in line with the formation of a special type of institutional arrangements like those that have developed in the region, particularly in the Southern Cone countries. As such, the figure of the paid worker was masculine. The "typical" labor relationship, therefore, was full time, regular employment during a working life with very few career changes. 0 bviously, women were at a disadvantage, obtaining some protection rules, but not achieving the principle of equality. What could legally have been correct, providing an opportunity for effective social solidarity, produced a fragmented, unfairly privileged system, based fundamentally on the differences identified in the labor market.

In due course, the overall improvement in working conditions, without any distinction for gender, eventually put an end to this special protection initially provided exclusively for women and children, and they gradually became the rights of workers of both sexes. By the 1950s, a slow and progressive process was embarked upon to eliminate from domestic legal frameworks the rules that breached this principle of equality, a process that unfolded heterogeneously and with different features in each country, and that occurred with the sanction of the ILO agreements on equality, proclaiming the principle of equality between the sexes. ${ }^{9}$

It is interesting to note that, since the mid 1980s, Latin American countries have, in conjunction with the reestablishment of democratic governments, reformed their Constitutions and assumed a significant number of commitments to their citizens to assure equality and equal opportunities in various social spheres. M oreover, they undertook, by ratifying international covenants and treaties, to assure equality and non-discrimination, not to mention the right to work.

In fact, the international declarations and treaties recognize the right to work, but with exceptions concerning the conditions in which they can be realized, making them subordinate to the resources and peculiarities of each State or to the obligation of the State to establish policies to guarantee this right. This is the case with the International Covenant on Economic, Social and Cultural Rights (ICESCR), which establishes that States Parties recognize the right to work, which includes the right of everyone to the opportunity to 
gain their living by work which they freely choose or accept. Each State Party agreed to take the appropriate steps to safeguard this right. The obligations of the States Parties are not limited to satisfying the minimum requirements of economic, social and cultural rights; they include the adoption of measures to fully and progressively satisfy these rights, using the maximum of their available resources.

The first international instrument to address discrimination against women specifically is the Convention on the Elimination of All forms of D iscrimination against Women - CED AW, which defines as discrimination

distinction, exclusion or restriction made on the basis of sex which has the effect or purpose of impai ring or nullifying the recognition, enjoyment or exercise by women, irrespective of their marital status, on a basis of equality of men and women, of human rights and fundamental freedoms in the political, economic, social, cultural, civil or any other field. ${ }^{10}$

The whole document promotes the creation of affirmative action policies to improve opportunities for the economic, social, cultural, civil and political participation of women. Concerning female employment, the CEDAW addresses not only the demand for employment, related to the criteria for selection, equal remuneration, social security, protection of health and maternity, but also the provision and expansion of the autonomy of female workers, related to the choice of work or profession and to professional training. ${ }^{11}$ It also provides for the right of women to family benefits, regardless of their marital status ${ }^{12}$ and plainly states that the rights of female workers should be protected from potential discrimination on the grounds of marriage and/or maternity. It clearly establishes that States should take all necessary measures, including sanctions where appropriate, to prohibit this form of discrimination and protect maternity through paid leave and prevent women from any involvement in work that could prove harmful during pregnancy. 0 ther ben efits include the provision of childcare and other services that enable parents to combine work and family responsibilities. ${ }^{13}$

This process of incorporating equality principles through constitutional channels or through international treaties and conventions was accompanied in many cases by the implementation of an equal opportunities policy at the behest of organizations for the protection of women in each of the countries in the region, organizations that very often have state or local chapters.

$\mathrm{N}$ evertheless, in spite of the progress asserting the principle of equality, in the majority of the countries in the region the 1990s brought with them neoliberal structural adjustment policies that, among other things, triggered profound economic changes together with tax reforms and labor market 
flexibility measures, accompanied by harsh restrictions against job security and social institutions. ${ }^{14}$

As a result, there currently exists in the region a distinct asymmetry between the constitutional frameworks with their broad consideration for equal opportunities, an important breakthrough in domestic equality policies, and the lack of effective enforcement mechanisms, in the context of consolidating the participation of women in urban labor markets. ${ }^{15}$

In this new context, the problem is not that women are considered and protected as "mothers", but instead, in light of these deficient employment policies, the problem is precisely being or wanting to be a mother. In other words, maternity, in the context of labor flexibility, has become a source of disadvantage for women. $\mathrm{H}$ iring women is discouraged as a result of allegedly higher labor costs, ${ }^{16}$ no reproductive services are provided and, in cases of absolute deficiency, female employees are actually penalized if they "infringe" the rules and become pregnant. Therefore, maternity is transformed from a social function protected by the State into an individual issue that, compounded by the denial of social services from the State, further complicates the situation of female workers in the majority of Latin American countries. In the case of informal workers, who enjoy no protection whatsoever, the problem is more serious still: they depend, in the best of cases, on the "goodwill" of their employers.

In other words, the current situation in Latin America is al so characterized by the persistence of the culture in which the responsibility for taking care of children and the home falls primarily on women, and not on couples. Indeed, regulations in the majority of the region's countries reflect this phenomenon, by focusing on childcare leave, subsidies for maternity and the provision of day care services. While this is very obviously a cultural problem, it speaks volumes that the State reinforces it with legislation and policies and, in the very act of regulating employer-employee relations, assigns women a dual function.

It is precisely in the field of policies for greater conciliation between productive work and raising children (reproductive work) that affirmative action in labor regulations ought to be concentrated, to promote a genuine breakthrough in the principle of equality. I shall return to this point later, in the policies I propose.

\section{Is social security blind to gender?}

Security, as an objective of government policy, seeks to protect individuals from material risks and individual material insecurities typically related to illness, incapacity to work or difficulty finding employment due to loss of 
skills, lack of income for maternity or raising children, the need to guarantee income for retirement or in the event of losing the family provider. These situations, known as contingencies, should not be settled by public charity or forms of mutualism or cooperation, but instead through collective arrangements. In other words, social security translates into actions of the State grounded in formal legislation and guaranteed by social rights and by the technical and administrative intervention of the state apparatus. ${ }^{17}$

0 riginally, social security law was differentiated from labor law in that it did not seek to protect the paid worker as such, but instead it attempted to protect the integrity of the individual. As the system developed, and mechanisms were designed to ensure that ben efits were effectively received, beneficiaries included dependent workers and, in some cases, their family group, although in general the recipient of the benefits has been the dependent worker and not the titleholder. For unpaid workers, coverage was limited to a number of well-defined contingencies, although in most cases the protection was a consequence of voluntary adherence. In other words, the principle of universality has not been sufficiently developed, as it is still necessary to meet certain conditions to be eligible for benefits, one of which is being a paid worker.

In short, protected individuals are all those included in the formal coverage of the system who become potential claimants of the established benefits that are made available in the event of a contingency, provided they meet the necessary conditions (age, illness). These requirements may refer to the objectivization of the contingency (degree of disability, for instance), certain legal conditions (such as being married) or the affiliation with the social security system (length of membership or minimum contribution). Clearly, the system is not unconditionally accessible to all citizens.

The State plays a dual role in this system: on the one hand it recognizes the right to social security for all inhabitants, legislating and regulating accordingly. $\mathrm{O} n$ the other hand, it assumes the responsibility of providing benefits either directly or via an intermediary to the beneficiaries. This consideration is the origin and foundation of Latin America's principal Welfare States. H owever, these States boast differing degrees of structuring, which has resulted in fragmented systems with inadequate coverage and administration and financing problems.

In fact, coverage is paid for in general through a social insurance system financed by taxes on income; it is not based on a broader welfare system like in Scandinavian countries. For the benefits to be paid, it is necessary for each worker and their employer to support the system, since otherwise it would not work. That is to say, only contributors have rights, which is the basis of the contributive system. 
This not only exposes a legal and normative precision, it also determines how opportunities are distributed to the various members of society. That is, individuals with a formal job receive all the benefits and rights, not only as a result of their status as workers, but they also enjoy full citizenship, unlike people who do not have jobs. In the distribution of opportunities, women historically lose out, among other reasons because of the lack of recognition for reproductive work and given their low rate of inclusion in the public sphere. $^{18}$

Given the way things have developed, paid employment is the source of other rights and one of the elements constituting citizenship in Latin America, then employment ought to be a right that, in accordance with the principle of equality, is accessible to all citizens. For the same reason, ought not the right to social security be guaranteed to all citizens, regardless of their status as workers and contributors?

These questions raise a number of dilemmas concerning the responsibility of the State as a guarantor of social security, both in the coverage of risks and contingencies, and in setting the basic conditions for the development of an autonomous existence, a fundamental principle of equity and equality.

As a consequence, since a paying job is the chief means for people to earn an income and also a means of social and personal inclusion, in the broadest sense, then observing a person's status in the labor market is a reasonable starting point for addressing the different expressions of social problems and discrimination that currently prevail. It is the role of the State to guarantee this inclusion.

To illustrate this point, female work presents the following characteristics: on the one hand, a paying job for women is central for their personal fulfillment and for exercising their autonomy, while it also has a certain character of emancipation of traditional family and cultural standards, and constitutes a source of income that provides the security for them to negotiate new family arrangements, not to mention helping prevent domestic violence. $\mathrm{O}$ the other hand, a large number of women do not have "productive" jobs, primarily because the market cannot absorb them, nor will it be able to. This is because involuntary unemployment is steadily rising and labor "disqualification" occurs when people accept jobs they are overqualified for, or in virtue of gender discrimination. Finally, "reproductive", or unpaid domestic work, done basically by women, is considered to be "socially useful", but still unpaid.

Gender discrimination, either in the wage-earning job market or in relation to domestic tasks is, in fact, one of the many forms of a far more complex problem: the methods of social inclusion and the ways in which cohesion is maintained in profoundly unequal societies. We should not fail 
to recognize that the availability of a job, either formal or informal, or entry into contemporary societies where market regulation prevails, are essential elements for people's performance and choices and, obviously, the satisfaction of their needs. Poverty clearly restricts freedom and curbs the performance or the "skills" of individuals, just as lower wages paid women for doing the same task as men, as a result of discrimination, reduces the possibility of fulfillment for women, and also undervalues their work.

The lack of a public policy approach from a gender perspective explains, in part, the state of the female labor market. The first indicator of this is that female inclusion has been largely precarious and involving low-qualified tasks in the informal market and, as such, having no social security coverage. A nother feature that is perhaps less visible, or at least more difficult to quantify, but nonetheless of significant importance, has been the reduction in the quality of existing jobs. In response to the imbalances apparent on the wage-earning job market, a discourse emerged in official circles, backed by experts from multilateral credit organizations, revealing that the difficulties of entering the labor market are centered on the way people offer their labor power on the market, placing the responsibility, therefore, squarely on the individuals for their status and track record in the labor market. ${ }^{19}$

Therefore, as women started to become regular participants in the labor market, it became clear that there was a lack of social security for them. Their arrival occurred in a context of greater restrictions, more informal and precarious labor markets, and notorious coverage flaws in the social security systems.

As such, public policies introduced over the past 20 years in most countries in the region have been founded on the principle that women are holders of rights that are derived from other rights, never actually holders of the rights themselves. ${ }^{20}$ Consequently, the political strategies adopted have been concerned with streamlining the methods of detecting and classifying the needs of women, the access to professional training, the allegedly higher labor costs and rates of absenteeism associated with maternity, among other things. They have not been based on the assumption of the existence of a differentiated power structure that generates asymmetric relations. Therefore, the impact of economic and social policies on women has not been taken into account. Instead, a "veil of ignorance" has been legitimized in terms of the non-neutrality of macroeconomics concerning gender.

So, what is the responsibility of the State when it comes to guaranteeing employment and social security? O ne element, which is fundamentally related to distributive justice, refers to the gender division between paid "productive" work and unpaid "reproductive" domestic work performed primarily by women, and is reflected in labor regulations. $M$ eanwhile, there 
is also a division in paid employment, discriminating between better paid, higher skilled jobs usually in industry that are male dominated, and poorly paid, less skilled jobs with lower productivity in the services sector that are considered "typically" feminine occupations. This situation occurs when the State neglects its social functions, requiring households and, in particular, women to take on greater responsibilities to satisfy basic needs and for social reproduction tasks.

Returning to the crux of the question, does this situation imply that the social security system should intervene by protecting, ahead of definitive unemployment, coverage for the entire working cycle of individuals and also assume responsibility for their training, to provide the conditions for them to improve their mobility in the job market? W hat should the State assure: employment or the job position?

$\mathrm{H}$ ere we come up against another ongoing argument concerning thelimits of social security, not due to the capacity of the State to provide this service, but given the difficulties of funding the system. As I pointed out earlier, the legal frameworks and numerous international conventions guarantee the right to social security, but in reality restrictions are imposed due to public finance. At this point a digression is necessary: sectoral reforms across Latin America have been extremely expensive, and countries have spent huge amounts of resources, in most cases in foreign debt money, concomitantly granting fewer benefits, of lower quality and at greater expense. In other words, the resources are available for reforms, but not to pay benefits.

So now another question crops up: is it possible to implement in countries in the region a dynamic domestic policy whereby decisions on social public spending are made through direct democratic processes in which the final assessment of the role of the State is based directly on the needs and preferences of its citizens?

We can see, then, that the objectives of social security are contingent upon funding, this being the key argument used to block amendments to the reforms al ready in place. That is to say, "ceilings" and limits to social security funding are constantly established, or direct reductions in the resources earmarked to social public spending for benefits, although we hear very little, for instance, about the fiscal cost of the transition from one pension system to another. ${ }^{21}$

This means that we cannot establish simple causalities that reduce the problems of social vulnerability to economic stagnation, nor can we dispense with economic growth if the objective is to reduce vulnerability. U ntil now, we have considered it the responsibility of the State to guarantee social security. As Ewald points out: "Social responsibility is the modern form of politics". ${ }^{22}$ In Latin America, however, we can observe how it was transformed into non- 
politics, or the lack of responsibility of the State to its commitments, allowing the new hegemony of the market to prevail.

It is interesting to take a look at the argument formulated by Folbre, who claims that one way of facing this challenge is not to think of markets as intrinsically bad to recognize "who owns what", nor to encourage the overvaluation that economists make of this abstraction called "the market", but instead emphasize that women have a legacy of responsibilities in care provision that should make them suspicious of the principle of "every man for himself". ${ }^{23}$ In other words, it is important to take a fresh look at the classic trilogy: State, market and family, to see what roles and responsibilities rest with each of them in this new scenario.

\section{C ourses of action: a new vector of social integration}

Social security and full employment are unresolved issues for women in Latin America. Although the growth in labor market informality across the region frequently affects men, there is still a certain institutional inertia they benefit from, and they not only enjoy more possibilities for access, but they also have a certain culture of social security that enables them to incorporate or avail themselves of its protection content. For women, however, particularly those with fewer resources, coverage for contingencies is an inaccessible ideal, while the urgency is constantly present.

Consequently, it is important to emphasize the need to shift the focus of intervention, continuing with the premise that it is necessary to achieve a greater incorporation and participation of citizens, male and female alike, in the labor market, while also considering the limits. That is, devise and propose policies that are not based on the illusion of creating new jobs in depressed labor markets like those in Latin America, but that instead consider social security as a new vector of social integration.

O nce again, it consists of proposing ways to consolidate social security networks and not social protection systems. It is necessary to determine precisely the limits of the term "social protection", which has begun to replace "social security", representing a clear setback. The term social security used to refer to a broad welfare package, with the State playing a strong role not only in provision, but also in regulation and funding. In contrast, the term social protection suggests a much more limited model, marking a shift from broad State action to a scheme in which individuals, households and communities play a much more active role.

Similarly, the first institutions that sought to reform the social security system were precisely those that had the most chances of being "offered" to private administration, as is the case with the pension system. The central 
characteristics of the reforms, with differential impacts, can be summarized in the following way: ${ }^{24}$

- privatization of the administration of social insurance (pensions, health insurance) reinforces the relationship between access to the institution and the situation on the labor market

- dismantling social institutions eliminates the "unconditional" networks of protection and reduces the effective level of coverage, both vertical and horizontal

- as a result, much of the responsibility for the coverage of social contingencies is transferred to citizens themselves, leaving them dependent to a large extent on their capacity to generate their own income

- there has been a greater selection and fragmentation of programs, since they are designed around the specific characteristics of different groups identified as the target population

- women, young people and the elderly are the hardest hit in this situation, as the only "solution" offered to them is to be the "beneficiary" of a targeted assistance program

- this fragmentation helps widen the social divide, as institutions representing "general interests" lose ground to those representing "private interests"

- the new scenario modifies the nature of conflicts and thus the role of the political actors. Previously, pressure was applied to obtain the expanding benefits, whereas now there is a struggle over the meaning of selectivity

- from a regulatory viewpoint, structures requiring public protection and collective actors have been abandoned, with full responsibility transferred to individuals, who are made directly responsible for their situation;

- in parallel, there are fewer institutions inspecting and reviewing the operation of the new systems, which has considerably increased the lack of protection for citizens.

The outcome of the pension reforms that endorsed individual commitment, based on the idea of "individual capitalization", as a solution to contingencies and also to the inefficiency of the State, has revealed a lack of structural development of the social system, aggravating the problems that existed in the former systems, while also promoting the inequality of the various systems and of society at large. Similar situations have occurred in relation to healthcare coverage, where the system of family coverage has been modified in most countries, and restrictively so. 
The situation grows more complex still when we add the problem of derived rights instead of inherent rights. The instability and vulnerability stop being circumstantial and become central. Just as informal employment in the labor market has quickly become the rule, not the exception, for new hirings, causing major instability in the foundations for building professional careers, coverage of social contingencies has suffered the same fate. This reality is now so deeply ingrained that the very institutions are acquiring contingent features, with a logic that is complex and inaccessible to citizens.

In this aspect, women lose out once again, since culturally and institutionally speaking their relation with social security has always been unequal. There is al so an important variable referring to new contingencies: there is no coverage and the topic is not open for discussion. There are gender-specific contingencies that have not been incorporated by the reforms.

Pension legislation exposes the lack of promotion of opportunities to access the system, to expand coverage, to raise contributions, to reduce risks and to even out the actuarial calculation. This lack of promotion differs considerably between men and women and ultimately results in inequitable conditions for women. O nce again, the main forms of discrimination are gender inequality in the labor market and disregard for reproductive work.

The numerous studies conducted on the pension reform ${ }^{25}$ have shown that the conditions for acquiring a pension right in the reformed legislations follow a pattern that, in general terms, is common to them all. M oreover, in each of them we can observe specific regulations that exhibit neutrality in terms of gender. Thus women are directly discriminated against, since they are not considered citizens and rights-holders. In the best case scenario, they are considered workers. A significant number of women are treated as dependent spouses, housewives and mothers, while an almost negative valuation is attributed to domestic work, as women who exclusively do to this kind of work are considered "dependents" and "beneficiaries" of their husband's pension. This benefit is not available to economically active women, even when they also dedicate their time to domestic work. Their paid work and savings appear not to have any value. In Chile, for example, widowers do not receive pensions. Additional unfair treatment concerns retirement age, which for women is five years earlier than for men. In view of this, and because of their higher life expectancy, women in an individual capitalization system receive lower pensions. ${ }^{26}$

The new pension systems reproduce the occupational and wage discrimination that affects women. This is a very important point, since it is usually argued that problems intrinsic to the labor market cannot be attributed to the pension system. Although this is true, numerous studies have illustrated 
the presence of discrimination and problems inherent in the pension system that reproduce inequities in the labor market. The reform did not take into account, for example, that stable employment is no longer the rule; instead, flexible labor, wages and working hours predominate. $\mathrm{N}$ either did it take into consideration the changes in the production systems. ${ }^{27}$

\section{O nce again, the centralism of the State}

No change will be possible without a political commitment to apply an ethical and political principle of gender equality. An equality that does not merely imply an improvement in conditions for employment and coverage of social contingencies for women, but one that involves a commitment to challenge the current systems of distributing opportunities and - let's face it - the capacities of women and men.

In other words, what is required are not simply technical changes to the reforms that have already been made, but instead a new political consensus embracing the principles that are at play when it comes to social inclusion. In turn, inclusion will only be achieved when social security is viewed in its broadest sense, and not just restricted to the pension system. Therefore, the centrality of the economic model in which the social security systems are a part is indisputable and key to any political decision that is taken.

This makes it necessary to introduce into the political sphere of Latin American countries the debate on who should guarantee social security, the exact responsibility of the State and the principles upon which it should be guaranteed, and also whether it should be based more on programs focusing on people who are not included in the labor market or with informal jobs. In other words, whether it is provided as a type of aid program, or whether social security should be guaranteed as a right of all citizens, that is, an inherent right that can be immediately accessed.

Also to be incorporated definitively into the agenda of governments are thorough assessments of the reforms that have been implemented, to understand why these policy options have produced the aforementioned results. It is worth noting that the exclusionary dynamics in place in the majority of the countries across the region do not only observe the application of technical equations, but they are based on cultural and social contents that del egitimize the social security institutions and the memory of the Welfare States in the region, and that are absolutely blind to gender issues.

Another issue key to the political discussion is the sparse realization of social rights as a constitutive part of the development of countries in the region. ${ }^{28}$ It is worth pointing out once again that these affirmations are not only propositional, but operative. There is no way to effectively fight 
discrimination if universal social security networks are not created with greater impacts on less autonomous social groups. For example, by including women in institutional agreements that solve the problems of social insecurity and precarious labor conditions that affect the majority of the population. The solution does not lie in isolated actions aimed at offering temporary relief for irreparable damages, but instead in stable policies that provide the conditions necessary to prevent people from falling into marginality and exclusion. These networks should function permanently to provide guarantees to all citizens from the moment they are born.

This topic is related to the principle of equality. It requires, firstly, an identical legal status and, secondly, the effective realization of life opportunities. Although the first principle is guaranteed de jure both in domestic constitutions and international covenants and treaties, the same cannot be said for standard of living, which is not the same for everyone, nor are there any guaranteed minimum standards for each individual.

The idea of social security has been erased in the context of situations that represent greater insecurity and vulnerability. Even though this may be a consequence of the reforms, it does not mean that is should be abandoned as a system ideal. Although social security has become insecure, it does not mean that it should be transformed into a rule for future models. $\mathrm{O}$ n the contrary, it should contain instruments to minimize these consequences. ${ }^{29}$

It becomes necessary, once again, to consider the idea of proposing comprehensive actions in the context of patterns of income distribution and patterns of residual capacities that occur in Latin A merica. We have to consider the reasons why Latin American societies have such a low redistribution capacity to be able to place within these limited patterns the effects of new reforms. What follows is a set of proposals to formulate comprehensive policies that ai $m$ to combine productive work, reproductive work and a comprehen sive social security system. That is, a broader spectrum than just sectoral policies and affirmative actions, one that also embraces and energizes them.

\section{Policies and affirmative actions}

These proposals may be placed into two forms:

- treatment of people as individuals with inherent rights of their own, as male or female citizens, without any preconditions

- strategies to implement and guarantee these inherent rights, which in this paper we shall call related rights. 
How do we make this shift from the category of contributing worker to a system that, albeit partially contributive, prioritizes the category of citizen? Is this possible? $C$ an this shift be legitimized?

To be sure, we consider that it is not only possible, but necessary. There is also a legitimacy to this proposal, since it is nothing more and nothing less than considering what has already been established: women and men are entitled to citizen rights, which consist of civil, political and social rights. Instead of considering capacity associated with a category (worker, contributor), the only thing to be considered should be the status as a citizen.

The first step towards achieving the legitimacy of this proposal is to consider social security in its full scope, and not only limited to the pension system or other social insurances. The system needs to be reorganized, with a view to strengthening new forms of coverage for social contingencies (biological, socio-economic and pathological), while considering the specifics of gender in each case and incorporating actions, today isolated in social policies, into a systemic whole.

This gives rise to a new question: how to consolidate reforms that embrace equality without being yet another burden on the salary of workers? T his has not been the topic of much discussion, since in most countries the solutions to the lack of funding of reformed systems come in the form of new contributions borne primarily by workers and, secondly, by employers.

The actions that need to be implemented, and that are considered socially useful for all society, cannot and should not be funded by social contributions, including, among other things, employment policies; unemployment benefit; measures for the conciliation between family care and work; maternity; and consideration for other unforeseen periods, such as raising children, training and studying.

$\mathrm{O} n$ the other hand, most countries in the region have signed international human rights covenants and treaties, which they are obligated to observe. They represent minimum obligations. These requirements are based on the exercise of a full citizenship and belong to the field of fundamental human rights. So, what do related rights consist of?

In the context of policy proposals, related rights are actions and guarantees that, respecting a minimum content, need to exist to effectively guarantee the exercise of a right to social security.

Returning to the idea expressed at the start of this paper, the new vector of social integration should not beformal paid employment, but instead a redefined system of social security. That is, no longer linking benefits to the status of a paid worker, but considering the rights of each citizen, male and female alike.

In this way, one of the first related right that can be guaranteed is the incorporation into the marriage contract of the possibility of shared 
contributions to the pension scheme, which in principle is not established in civil regulations - with some exceptions - in Latin America. As such, in the case of divorce, the contributions made during marriage by both spouses can be considered marital assets. The law calls for a 50-50 division between spouses of the contributions made by them both during the marriage. This should be considered an inalienable right. ${ }^{30}$

The situation is decidedly simple and it does not in any way affect the pension system. All that is required is a different approach, treating the pension contributions made during marriage or common-law relationship as an inherent right and considered as a marital asset. As a result, the inherent rights of women are highly likely to be strengthened.

For the purpose of effectively incorporating and promoting the development of a system that considers the rights of women as inherent rights, the proposal is to consider the periods of contribution for women - which continue to be shorter than those for men, both in duration and in terms of the value of the contribution, in spite of the plans for equal treatment and family conciliation - to be lower than those required for men or to compensate age for years of contribution or vice-versa. This proposal is based on the understanding that an increase in the remunerated activities of women is not enough to secure a retirement pension without resorting to derived rights.

0 ne of the reasons why women never achieve the same size pension or welfare benefit as men is because they put their working life on hold to raise children, because they do part-time work or due to discriminatory practices (salary, occupational, among others). These situations are reflected in the value of the pension or welfare benefit. The reform of the pension system conducted in G ermany in 2001 is particularly illustrative, since it incorporated an additional accessory to the pension depending on the number of children in the household. This accessory, the exercise of an inherent right of women, also applies for widow's pensions. ${ }^{31}$

Therefore, we could consider incorporating provisions like those established in Germany, whereby women who have contributed to the social security system for 25 years have a basic contribution covered for a period of 10 years immediately following the birth of a child, considered as if it were done by the average covered contributions of all those insured in the year in question. In this way, part-time work is not penalized, because if it were calculated as contribution time, the calculation base would be very low, which means that any resulting pension would also be low. When work is put on hold to care for a child that cannot work and is aged under 18 and, as a result of the dependence of the child, one of the parents has to dedicate at least 28 hours per week to their care, the covered contributions are considered as if it were the average of all those insured. 
This reasoning needs to be complemented with another situation: while we refuse to accept that child-raising tasks should be considered in the public sphere, and not in the private sphere, no progress will be made in the situation for women. Issues such as the division of domestic work and the treatment of women as "dependents" will remain in force and there will be no changes in the pension coverage for unpaid women. $\mathrm{N}$ either will there be any recognition that child-raising tasks are crucial for the generation of social capacities, which are indispensable for the development of a person and their opportunities.

\section{Stretching the limits...}

This analysis has resulted in a favorable context that supports the experience of achieved goals, such as those described throughout this paper. N evertheless, it would be recommendable to select a set of affirmative actions on work and social security that promotes a shift in the quality of the actions already developed. In this paper, we have presented some that will no doubt spark debate, but by no means do we consider them conclusive and exhaustive.

In fact, we need to evaluate the limitations presented by this combination of restrictive regulatory frameworks, within the context of structural adjustment processes, and affirmative actions promoting equality, and whether the latter have remedied the existing discrimination. A quick look at the legal texts and equality policies in place would make it look like they have. H owever, statistics on occupational and wage discrimination and on the various forms of segregation, combined with the precariousness and low or inexistent coverage of social security and contingencies in general offset the successes that have supposedly been achieved.

$\mathrm{H}$ ere I shall raise a specific recommendation. It is not about including and incorporating more rights, but instead about reviewing the rights al ready established and recognized by international instruments and domestic legislation, and verifying whether they satisfy the minimum social rights standards. ${ }^{32}$

For this reason, it would be important to submit to review many of the sanctioned rules or associated rights and determine whether they observe the established requirements. This type of control of legitimacy is important to keep track on numerous policies, programs and actions that grant rights, and that are not al ways legitimate. Conversely, the obligation to guarantee essential levels of rights obligates the State not to interfere with this minimum content by restricting them, considering that all restrictions on economic, social and cultural rights should be submitted to a review to ascertain whether or not the essential content of the regulated right has been interfered with. ${ }^{33}$

Finally, but by no means any less important, it is essential to address 
mechanisms for the inclusion - and not just regulation - of the huge numbers of informal workers that exist in Latin America. Until we provide them with the same rights and duties as formal workers, equal treatment and opportunities for men and women will never be an operating principle.

Consequently, it is the State at all its levels that needs to spearhead the process of change, as a result of the obligations it assumed upon ratifying international instruments, both those dealing with human rights and the more specific ones on social rights, reaffirming the pursuit for equality.

O nly when we develop integrated systems, whether centered on employment, considering the differences and discriminatory situations that we need to remedy through affirmative actions, or on social security as a vector of integration, will we be on the right path towards implementing the principle of equal opportunities.

In other words, it is about more than just guaranteeing employment and social security, but about making it accessible to all members of society, under equal conditions, and by doing so achieving a form of social inclusion that not only comprises the spheres of formal employment, but that spreads into all spheres of public life. It is about combining citizenship with the effectiveness of rights. 


\section{NOTES}

1. R. Castel, La Metamorfosis de la Cuestión Social. Una Crónica del Salariado, Buenos Aires, Paidós, 1997.

2. R. Dworkin, Taking Rights Seriously, London, Duckworth \& C0, 1977. Dworkin makes a distinction between "equal treatment" and "treatment as an equal". The principle, he argues, is that people ought to be treated "as equals" (that is, people who have the same moral right to pursue a freely chosen life plan and to be treated with the same respect as anyone else), giving them adequate use of the resources at their disposal, which enables them to take advantage of the opportunities that present themselves. The right to the "same treatment" may only be derived from the other principle.

3. Public law refers to the relations between branches of the State or between these branches and individuals, while private law governs the relationships between individuals. In this division, the acceptations public and private carry different meanings than those attributed them when the focus is gender. Hereinafter in this paper, this is the meaning I shall employ; with "private" designating the space and the relations inside the home and "public" representing the space, processes and relations outside the home. L. Pautassi, E. Faur \& N. Gherardi, "Legislación L aboral en Seis Países Latinoamericanos. Límites y Omisiones para una Mayor Equidad", Serie M ujer y Desarrollo, n 56, Santiago de Chile, ECLAC, 2004.

4. In the majority of labor codes and specific regulations in Latin America, this dichotomy has been resolved by prioritizing the protection of maternity, not equality. Once again, this option is in line with the commitments assumed by the States in international conferences (in particular CEDAW), International Labor Organization (ILO) conventions and domestic equal opportunity policies, while it also reflects the limitations imposed by the nature of the legal discourse. It also incorporates the principle that not all inequality implies discrimination, meaning the assurance of equality should not imply equal treatment for those who find themselves in different circumstances.

5. See, on this subject, L. Pautassi, E. Faur \& N. Gherardi, op. cit.

6 Some of the points analyzed here have already been presented in Laura Pautassi, " ¿Bailarinas en la Oscuridad? Seguridad Social en América Latina el M arco de la Equidad de Género", a paper presented at the Thirty-Eighth Meeting of the Presiding Officers of the Regional Conference on Women in Latin America and the Caribbean, Mar del Plata, 7-8 September 2005.

7. These principles are found in the domestic legislation of every Latin American country, in the legal framework that contains the political constitutions, labor codes (when these exist) and other complementary laws and regulatory provisions. International human rights treaties and International Labour Organization (ILO) conventions also have a significant influence on this framework, since besides being of mandatory application for domestic courts, they have also orientated some guidelines of domestic legislation. See Pautassi, Faur \& Gherardi, op.cit.

8. Conventions $3,13,41,89,103$ and 127.

9. Conventions $100,111,156$ and 171 . Nevertheless, this evolution was not entirely linear and for many years, from 1919 to 1981, various approaches to female work, including various legally 
protected interests, overlapped: women as weak individuals requiring special protection, women as mothers, maternity, equality and, finally, protection of maternity/paternity. Flavia M arco, "Consecuencias E conómicas de la Discriminación Laboral por Género", Masters thesis in E conomic Law, Santiago do Chile, University of Chile, Law Faculty, Graduate School, 1999.

10. U nited Nations General Assembly, Convention on the Elimination of all forms of Discrimination against Women (CEDAW), 1979, article 1.

11. Ibid., article 11 .

12. Ibid., article 13 .

13. I bid., articles 11 and 12 .

14. Pautassi, Faur \& Gheradi, op. cit.

15. It is worth pointing out that the amount of women active in the urban job market between 1990 and 2004 rose from $37.9 \%$ to $51 \%$. This is a sizable increase, although still far behind the figure for men, which in 2004 was $78 \%$. Latin America presents the widest unemployment gap between men and women: $3.4 \%$ in 2003. Economic Commission for Latin America and the Caribbean (ECLAC), Gender Statistics, Women and Development U nit, 2006, available on the internet, at the link <www.cepal.org/mulher/proyectos/perfiles/default.htm> or <http:// www.eclac.cl/mujer/proyectos/perfiles_en/default.htm>, accessed on J anuary 16, 2007.

16. An analysis of the structure of labor costs by gender conducted in five countries (Argentina, Chile, Brazil, Mexico and Uruguay) reliably confirms that it is indeed a myth that hiring women implies greater labor costs. L. Abramo \& R. Todazo, Cuestionando un Mito: Costos Laborales de Hombres y Mujeres en América Latina, International Labour Organization, Lima, 2002.

17. Claus Offe notes that none of these questions have been established in a straightforward and unquestionable manner, hence the ambiguous and obscure nature of social security. Claus Offe, "Un Diseño no Productivista para Políticas Sociales", in Rubén Lo Vuolo (comp.), Contra la Exclusión. La Propuesta del Ingreso Ciudadano, Buenos Aires, CIEPP/M iño y Dávila, 1995.

18. The "full" inclusion of women will only occur when they enjoy all formal rights, particularly educational rights. People who are not included in the formal labor market and, as such, do not contribute to the social security system, do not enjoy these rights. In this vein, there is a sizable contingent of women labeled "inactive", who are placed in this category for the simple fact that they do not have access to the labor market, basically because of their domestic responsibilities.

19. This discourse has been emphasized in recent years to illustrate the need to resolve the problem of economic recession as a preliminary measure for improving the situation on the labor market. While it is obvious that the chances of improving opportunities on the labor market without economic growth are next to nothing, the opposite is not necessarily true.

20. A paradigmatic example of this are the numerous and varied social programs designed and geared towards "vulnerable groups". In these, women appear as the principle group subject to vulnerability and they are treated as "beneficiaries" or "recipients" of specific programs, not as 
holders of rights. As such, they are beneficiaries of a "program for" (maternal and childcare programs) and not holders of "a right to" (healthcare).

21. See on this subject Carmelo Mesa Lago, "Desarrollo Social, Reforma del Estado y de la Seguridad Social en el Umbral del Siglo XXI", Serie Políticas Sociales, № 36, Santiago de Chile, $E C L A C$, J anuary 2000.

22. F. E wald, L'E tat Providence, Paris, Bernard Grasset, 1986, p. 540.

23. Nancy Folbre, The Invisible Heart. Economics and Family Values, New York, The $\mathrm{N}$ ew Press, 2001.

24. Here, we once again take up the topic developed in Laura Pautassi, "Legislación Previsional y Equidad de Género en América Latina", Serie M ujer y Desarrollo, n 42, Santiago de Chile, ECLAC, 2002.

25. See, on this subject, Flavia M arco, Los Sistemas de Pensiones en América Latina, Un Análisis de Género, Santiago de Chile, ECLAC, 2004.

26. Flavia Marco, op. cit.

27. Flavia Marco, op. cit, p. 33. Based on empirical evidence from the pension reforms in various Latin American countries, the author asserts that both individual capitalization schemes and public pension systems distribute benefits inequitably. However, she adds that "social security can and should observe a function to correct social inequalities. This reasoning answers the question as to whether or not pension deficiencies are attributable to the labor market and whether this market is one of the various spheres of application of social policies".

28. For an analysis of the gap between rights and the development perspective, see Victor Abramovich, "Una Aproximación al Enfoque de Derechos en las Estrategias y Políticas de Desarrollo", ECLAC review, n 88, Santiago de Chile, ECLAC, A pril 2006.

29. Mario Paganini, Financiamiento de 10 Inestable, Santa Fe, mimeo, 2002

30. It is worth pointing out that countries such as Germany incorporated shared pension contributions as an inalienable right since 1977.

31. Fidel Ferreras Alonso, Adaptar la Seguridad Social a las Nuevas Situaciones Sociales: EI Ejemplo de Alemania, Madrid, mimeo, J une 2001.

32. Among the most common standards, those recognized as minimum content of rights are those of progressiveness and non-regressiveness; of non-discrimination; of information production and policy formulation; of participation of sectors involved in the designing of public policies and of access to technology. Centro de E studios L egales y Sociales (CE LS-Argentina), Plan J efes y J efas. ¿Derecho Social o Beneficio sin Derechos?, Colección Investigación y Análisis 1, Buenos Aires, CELS, 2004.

33. Abramovich, op. cit. 